\title{
2. Women expatriates: a research history
}

\section{Susan Shortland}

\section{Introduction}

This chapter traces the history and provides a critical review of the extant literature on women's participation in expatriation. It begins by reviewing the literature from the 1980s, examining Nancy J. Adler's seminal work and how her three key 'myths' (relating to supply and demand, namely that women do not want international careers, organizational reluctance to send women abroad and presumed lack of host country acceptance of women expatriates) provide explanations for their minimal expatriate representation (just $3 \%$ in the early 1980s) and set the scene for over three decades of female expatriate research. The following three sections examine the female expatriate literature on these themes in depth and in so-doing provide analysis at the individual, organizational and societal levels. They preview: evidence concerning the individual choices that women make and the effect of family constraints upon these; organizational decision-making, particularly in relation to expatriate selection; and the effects of societal cultures (at home and abroad) on women's expatriate participation. These issues are framed theoretically, set within the global context and within women's participation in international management more generally.

While women's expatriate representation has increased over the years, they still remain in the minority, comprising around one-fifth of the expatriate population today (Brookfield, 2012). This proportion has changed little over the last decade, suggesting that this may represent the limit of female international assignment participation. Men dominate 
expatriation in countries such as Japan. Although firms based in Asia-Pacific are beginning to send more women on assignment (Anon., 2007), where considerable participation by Japanese and other Asian organizations is included in survey data, for example ORC Worldwide (2007), female expatriate participation is lower (Thang, MacLachlan and Goda, 2002). By comparison, Asia-Pacific headquarters-based organizations comprise only a small percentage of respondents in Brookfield's (2012) survey which records higher female expatriation. The academic research into women's expatriation reflects the predominance of Western women from North America, Europe and Australasia going on assignment (Shortland and Altman, 2011) and hence the experiences of female expatriates from these regions form the main focus of this chapter. However, going beyond Adler's themes, this chapter also examines institutional factors and their impact on women's entry into, and support within, expatriate roles. The chapter concludes with a critical review of what we actually know about women expatriates (surprisingly little after 30 years) (Shortland and Altman, 2011). It includes the effects of organizational interventions, the changing nature of expatriate assignments and gendered issues that potentially hinder or alternatively facilitate women's international mobility, ending with a call for theoretically framed further research.

\section{Women's expatriation: the early years}

Academic research into expatriation before the 1980s is relatively limited. Edström and Galbraith's (1977) seminal paper emphasizes headquarters' strategies to co-ordinate and control subsidiaries through the use of expatriates and firms' reliance on 'trusted' managers. Although organizational bureaucracy creates certainty, Kanter (1977) reports that firms experience much uncertainty and hence the importance of using trusted 
individuals particularly when emphasis on international expansion is increasing (Thal and Cateora, 1979). Yet, the hazards of international careers are already known, including the human stresses and sacrifices to be made by the 'geocentric man', his wife and family members (Perlmutter, 1969).

Although sex discrimination legislation has already set the stage for women's entry into management in the USA, the literature of the 1970s indicates managers still being stereotyped as male (Schein, 1973): men are reported as holding the top positions and selecting in their own image to maintain their closed circle of trusted individuals; women senior managers are identified as 'tokens'; the role of management is viewed as total devotion requiring absorptive and time-consuming careers; and women are assumed not to have the same level of dedication to their work as men. Women are also reported as being kept away from top roles through their deployment in staff or technical positions requiring expert or administrative capabilities, rather than in line functions in decision-making roles (Kanter, 1977). Even more limited opportunities are reported regarding women being able to move laterally from domestic to international divisions, despite international management experience being recognized as a necessity for promotion to the top (Thal and Cateora, 1979). It follows that women, not being fully socialized managers, are unable to access opportunities for 'strategic placement' within top management (Edström and Galbraith, 1977).

In her ground-breaking paper of 1979, Nancy J. Adler, the key figure in the academic community in drawing attention to the issue of women's minority participation in international mobility, explains women's de-selection from expatriation through the basic principles of supply and demand. Women, it is assumed, do not supply their labour - either by not applying for international assignments or by turning them down. In addition, 
women's suitability in terms of employer demand is questioned; either they are not considered suitable as candidates or, if they are, employers turn them down and foreigners reject them prior to transfer or on arrival. She reports that although emerging evidence suggests these barriers to women's entry into expatriation are 'myths', at this stage there is little systematic research to confirm or negate this. Yet, Thal and Cateora (1979) predict that pressure will come from middle management women to further their careers through foreign assignments, setting the scene for research into women's participation in international mobility.

\section{Adler's contribution in context}

In the early 1980s, academic articles exploring female expatriation are rare (Izraeli, Banai and Zeira, 1980). Adler's pioneering work in the field indicates women's expatriate participation as being just 3\% world-wide (Adler, 1984a). The significance of Adler's work should not be under-estimated as it forms the basis of research into women's participation in international mobility over the following decades. Indeed, it is notable that the issues deemed to limit women's expatriation (women's choices and family concerns, host country reception and employer perceptions) remain unchanged today (Adler, 2011).

First, Adler (1984a) explores whether women's attitudes to international careers and pertinent domestic issues affect their potential to take up international assignments. Via a study of male and female MBA students in Canada, the USA and Europe, she finds that women are equally as interested as men in international careers and there are no major differences in their reasons for rejecting an international assignment. Men and women both see foreigners' lack of respect for female assignees as a major barrier to women's selection and thus men are viewed as having greater international career opportunities than women. 
However, these areas of broad agreement mask differences in perceptions of international opportunities and the successes associated with them. For instance, she reports that men think that women have better chances of being selected and advancing successfully in an international career than women themselves do. Women view organizational reluctance to select them as a hurdle equal to foreigners' perceived prejudice - a view that is less ascribed to by men. Women think their international effectiveness is greater than their male colleagues do; but men see greater organizational rewards in pursuing international careers. The research also reveals domestic circumstances as having an effect on women's likely participation. Although married women are no less interested in international careers than married men, they are more likely to turn down a foreign assignment if suitable employment cannot be found for their spouse. Adler's findings lead her to suggest that organizational barriers to women's selection might impede women's progress more than the prejudice attributed to foreigners. She also suggests that societal pressure might influence women's selection: men's career continuity can be maintained while women's position in the home is reinforced.

Adler's research (1984b) into the reluctance of organizations to select women focuses to a large degree on gender. There are no advantages to being female from the organizational perspective: culture, foreigners' prejudice and dual careers are cited as obstacles to their deployment. Isolation, hardship, safety, loneliness and the impact of the move on male spouses and children are also issues of concern and posting women could potentially demean the position itself (Izraeli et al., 1980). Overall, the assumption that organizations are unwilling to send women abroad is upheld in the 1980s: women's supply characteristics make them unsuitable for an international assignment. 
Turning her attention to the intertwined supply and demand factors related to foreigners' acceptance of women, Adler's (1987) research considers women's self-efficacy and host nationals' perceptions of women assignees. Female expatriates assigned to a variety of Asian countries report that their gender increases their visibility to their advantage. They are not expected to act as local women, but are accorded a 'higher status' and benefit from a 'halo effect'. Locals view them as foreigners rather than women in the first instance and thus rules governing the behavior of local women do not apply to female expatriates. Jelinek and Adler (1988) draw attention to women's success, emphasizing relationship building and highlighting the value of this competency to business development in Asia. Adler's (1987) research dispels the assumption that women cannot succeed in foreign postings but it also confirms the veracity of organizations' reluctance to select women: the interviewees speak of the difficulties they face in selection and how their assignments are limited out of concern for their safety.

\section{Women's choices and family constraints}

From the 1990s researchers, following up Adler's first myth in their examination of women's willingness to undertake international careers, debate women's willingness to accept international postings. For example, female graduates in Europe are less inclined than men to reject foreign postings unless these affect their partner's career or income (Taillieu, 1992) while in the USA, female students show even greater interest in international assignments than men (Hill and Tillery, 1992). Yet, at this time, women are pessimistic about their access to these opportunities at senior levels (Chusmir and Frontczak, 1990). Nonetheless, Tung (1998) reports no significant differences between men's and women's willingness to accept international postings, Wang and $\mathrm{Bu}$ (2004) find 
women as receptive to international careers as men, Linehan (2000) reaffirms women's interest in international careers and Stroh, Varma and Valy-Durbin (2000a, 2000b) report that female expatriates and their supervisors agree that women are interested in expatriation. The academic literature is by no means unanimous in its stance, however. For example, van der Velde, Bossink and Jansen (2005) find men more willing to accept international assignments (but also more willing to follow their partners on international assignments than women), while Tharenou (2003) notes young male graduate employees are slightly more receptive to international careers than young women. Fischlmayr (2002) reports women knowingly behave according to stereotypical expectations and that they exhibit low self-confidence, suggesting that women themselves are partly to blame for their under-representation in expatriation. Lowe, Downes and Kroeck (1999) find that levels of cultural difference, development and political risk influence the variance between men's and women's willingness to accept international assignments.

The impact of dual careers, marital status and the family are identified as affecting decisions to accept international assignments (Chew and Zhu, 2002; Zhu, Luthans, Chew and Li, 2006). Juggling family commitments and the demands of international mobility are identified as placing particular strain on married women and those with children (Linehan, 2000). Indeed, Linehan and Walsh (1999a) note that women have to be better at balancing a number of competing duties than men and that sacrifice of personal life is common for those women who reach senior expatriate levels. Assumptions by employers that women are not interested in international roles and that married women in particular do not want them, mean that women have to ask specifically to be considered (Linehan and Walsh, 1999b). 
With respect to dual careers, the geographical mobility of a husband's career is reported as disruptive to his wife's career development (Hardill, 1998) and family life in general (Hardill and MacDonald, 1998). Progression in scientific careers, in particular, is identified as demanding high levels of international mobility resulting in the tendency of female partners to leave their careers or not progress in them (Ackers, 2004). Harvey (1995) suggests that, as the number of female expatriates increases, dual career issues are likely to exacerbate and he draws attention (Harvey, 1997) to a woman's concerns in supporting her male partner and family on assignment. However, assumptions that dual career issues are only a woman's problem are challenged in the literature: Diem-Wille and Zeigler (2000) suggest that dual career couples co-operate to discuss strategy and timing of action, advising and inspiring each other; while Gordon and Whelan-Berry (2004) acknowledge the trade-offs and sacrifices necessary to maintain such mutual support. Hardill, Green, Dudleston and Owen (1997) point out that, within dual career households, one career tends to be prioritized at any one time but this is not necessarily the male career. Linehan and Walsh (1999b) agree that the male career cannot be assumed to take precedence although they acknowledge unequal expectations as to how husbands and wives accommodate and support each other's careers. Stroh et al. (2000a, 2000b) find that women in dual career relationships accept slightly fewer assignments than those with non-working partners or single women.

The difficulties faced by spouses in adjusting to living abroad are well documented (Suh and Lee, 2006). International mobility is seen to impact on ability to take up paid work and it thus promotes a focus upon take up of domestic roles (Yeoh and Willis, 2005). This affects the couple's income as well as the financial independence of the relocated spouse (Sriskandarajah and Drew, 2006). Recognizing the increasing participation of 
women as expatriates in their own right, Punnett, Crocker and Stevens (1992) draw attention to the issues faced by male spouses, particularly in relation to their adjustment and opportunity to work in the foreign environment. Even though the female career cannot be assumed to be subordinate to that of the male, it is acknowledged that spouse-related problems are greater, particularly when men have to adjust to the role of secondary breadwinner. It is recognized that society judges men more than women by their career advancement; men as secondary careerists are deemed to have made a negative move, even to the extent that men's refusal of relocation because of the potential impact on the female spouse's career can be seen as 'career suicide' (Linehan and Scullion, 2001a). The problem is exacerbated through lack of corporate support to male spouses (Selmer and Leung, 2003a) while the focus remains on support for females (Harris, 1993).

It is known that a spouse's intentions to relocate internationally affect a manager's intentions to take up an assignment (Brett and Stroh, 1995; Dupuis, Haines and Saba, 2008; Mäkelä, Känsälä and Suutari, 2011). Expatriate performance and assignment success relate directly to spousal happiness and ability to adjust (Tung, 1982). The blurring of the boundaries between work and home and resulting work-family conflict as traditional family roles are disrupted are also documented (Harris, 2004a). The literature therefore suggests that marriage increases the risk of assignment failure, particularly for corporate women expatriates, due to trailing male spouses. Indeed, as female managers consider their spouse's career to a greater extent than do men in making assignment decisions (Linehan and Scullion, 2001a), the male trailing spouse is considered to be a major contributory factor in explaining the scarcity of female international managers (Linehan and Walsh, 2001; Linehan, 2002). The challenge to gender boundaries in the family and marital tension results in women holding back their careers to prioritize their marriage (Linehan and 
Walsh, 2000a) and thus women do not accept international assignments despite willingness to engage in them. While the literature focuses mainly on spousal issues influencing assignment take-up, being single, divorced or separated are also acknowledged as presenting problems for women in maintaining personal relationships. However, as Linehan and Walsh (ibid.) suggest, single status does, overall, enable greater international mobility. Responsibility for elder care is also an issue affecting women's international management careers (Ruhe and Allen, 1997) yet this is addressed by a relatively low proportion of employers; support for elder care has historically been limited and remains so today within expatriate policy provision (Brookfield, 2012).

Children's adjustment and schooling are also known to affect willingness to relocate internationally (Tzeng, 2006; Zhu et al., 2006) in particular to developing countries (Tharenou, 2003). Women bear primary responsibility for family life and caring for children (Gordon and Whelan-Berry, 2004) and, while work environments remain insufficiently flexible to enable women to balance international careers and family responsibilities (Linehan and Walsh, 2001), a major deterrent remains to women accepting international assignments. Both home country management and societal assumptions result in a woman's primary role being that of mother, not international manager (Linehan and Walsh, 2000a) and that it is women's commitment that is doubted once they become mothers (Linehan and Walsh, 2001). Linehan (2002) suggests that the guilt and conflict derived from the way society defines parental roles forces women to make choices and to experience greater sacrifices than men in pursuing international careers and in reducing work-family conflict. From the organizational perspective, family ties are seen as obstacles to promotion as these reflect availability essential for overseas assignments (Linehan and Scullion 2002a). 


\section{Women's choices: An expression of interest but not assignment commitment}

While the literature indicates that women, on the whole, wish to pursue careers in international management, their willingness to undertake expatriation is identified as a different issue (Andresen, Hristozova and Lieberum, 2006). For women - and men international mobility requires making choices and for whole families to live with the consequences of them. Rational choice theory (Becker, 1981) proposes that individuals act rationally to achieve their aims or to maximize or optimize their desires. Personal or mutual advantage can be gained through co-operative exchange and thus division of labor in the family and specialization in market or family work is deemed efficient. While women's apparent keenness to enter the international assignment labor market does not appear to fit particularly well with rational choice theory, the outcome in terms of willingness in practice (represented by their relatively low participation) is perhaps explained in part by it - the theory suggests that the differences in the sexes' distribution across jobs stems from role specialization in recognition of the limits arising from women's domestic responsibilities (Shortland, 2009). The concept of rational choice is integral to family power theory which concerns the relative resources of each partner in the decision making process within the family unit (Harvey, 1998). The family member with the greatest financial power can impose outcomes to further his/her career goals to the detriment of the partner's. This suggests that a couple would find it easier to accept the negative effects of an international move on one partner's career when the other had the higher income and/or better career prospects (van der Velde et al., 2005). 
Hakim's (2000) preference theory can perhaps explain women's choices to engage (or not) in expatriate work. The low percentage take-up of international assignments by women might possibly relate to women's preferences to put family issues ahead of their careers, either because of their home-centered pre-disposition or an adaptive preference during their life cycle. Corrigall and Konrad (2006) find that family responsibilities are significant predictors of both men's and women's preferences. Yet, preference theory suggests that women are typecast and that their choices are real. Hakim's (2000) theory is thus subject to much criticism; although career choices may reflect preferences they may also, to a greater or lesser extent, be borne from constraint. As Bruegel (1996) notes, preferences read into outcomes give no credence to the circumstances that frame them; and Crompton and Harris (1998) note that preference theory does not recognize the context that shapes choices made.

In summary, while the extant literature suggests that women want expatriate careers, this does not translate in reality into high levels of female participation. Theoretical explanations linked to labour supply and women's choices suggest that it is economically rational for women not to work in paid employment, specialising instead in raising their families (Becker, 1981), indeed preferring 'adaptive' or 'home-centred' roles (Hakim, 2000). Thus, this rhetoric suggests that take-up of expatriation is secondary to women's family responsibilities. Men's greater family power (Harvey, 1998) potentially cements women's 'home-centred' status and helps to provide a reason for their relatively low expatriate participation. Nonetheless, these explanations do not acknowledge the constraints under which women make their choices to engage in expatriate work.

\section{Organizational decision-making: expatriate selection}


Women face gender bias via stereotyping and preconceptions resulting in unequal treatment (Auster, 1993). They are also subject to structured and systemic discrimination in organizational policies and practices (Burke and McKeen, 1993). Thus, psychological and institutional practices (Miller, Neathey, Pollard and Hill, 2004) combine to create the 'glass ceiling' - defined as an 'invisible but impermeable barrier that limits the career advancement of women” (Burke and Vinnicombe, 2005, p. 165). This glass ceiling in domestic management appears to be 'double-glazed' for women expatriate managers (Harris, 1992).

Expatriates are generally selected from a managerial pool and although women's entry into this is beset by barriers (Liu and Wilson, 2001), once within it, the question arises as to why they are not considered suitable for expatriate selection. Egan and Bendick (1994) suggest that men hold the decision-making roles affecting women's careers while Varma and Stroh (2001) and Varma, Stroh and Schmitt (2001) note that supervisorsubordinate relationships (where supervisors are typically male) affect women's selection and deployment internationally. Harris and Brewster (1999) argue that 'the coffee-machine systems' of informal discussions and recommendations favor male expatriate selection. In effect, a 'glass border' applies to women's expatriation (Linehan and Walsh, 1999a); the glass border reinforces the glass ceiling and vice versa (Haines and Saba, 1999). The potential expatriate pool traditionally excludes women (Selmer and Leung, 2002). Perceptions of home country managers remain reinforced by traditional profiles of typical male international executives and the choice of candidates is limited, wherever possible, to employees well-known to the selectors (Linehan and Scullion, 2001b). The main obstacle to women's selection is therefore identified as their gender (Linehan and 
Walsh, 1999b; Linehan, Scullion and Walsh, 2001) and yet gender is rarely acknowledged in international deployment practice (Harris, 2004b).

Organizations do not always select openly for expatriate positions; informal targeting of potential candidates is typical practice (Westwood and Leung, 1992). Women find themselves excluded indirectly through misconceptions regarding their willingness to go if they have working husbands and/or children (Chan and Smith, 2000), through insufficient networks and their consequent lack of awareness of opportunities (Westwood and Leung, 1994) and in-group and buddy systems operating adversely against them (Daley, 1998). Prejudice against women in the selection process is in evidence: organizations simply prefer not to send women, citing the need to respect host country attitudes negative towards their deployment (Stone, 1991). Linehan and Scullion (2001c) report that line managers ignore selection criteria and prefer to rely on informal mechanisms of selection thereby reinforcing prejudice.

Harris (2002) reports on the effects of expatriate selection based upon formal or informal approaches using open or closed systems. Formal approaches include defined selection criteria and measures of suitability, training for selectors and the use of selection panels. Informal systems have less well-defined criteria, measures and limited (or lack of) training and the use of panels. Open systems are characterized by advertising of all vacancies and interviews supported by formalized testing. Closed systems are characterized by nomination of suitable candidates to line managers with the candidate being informed once acceptability has been agreed. Where closed and informal selection systems are used, selectors are not forced to question their assumptions and a lack of consistency and clarity in selection criteria results, not conducive to women's participation. Where international 
management selection is carried out in a formal and open manner, equal opportunity considerations included within the selection process favor women' selection.

\section{Human and social capital as explanations for women's paucity as expatriates}

Women believe that they have to be better qualified and more ambitious than their male counterparts to be selected for an international assignment (Linehan and Walsh, 1999a; Linehan, 2000) and they have to persuade home country management to take the risk to send them (Linehan and Walsh, 1999b). Yet, women expatriates do possess suitable characteristics to produce successful expatriate outcomes. For example, Gordon and Teagarden (1992) report that women's cross-cultural relational skills are associated with expatriate success and Selmer and Leung (2003b) find that female expatriates have higher work and interaction adjustment than their male colleagues, with women's interaction adjustment linked to their determination to pursue an expatriate career (Selmer and Leung, 2003c).

Human capital theory states that people are rewarded for their previous investment in education and training. It suggests that, in respect of labour supply, women have less human capital to bring into the labour market in terms of their education and also in relation to the human capital they develop within it (Miller et al., 2004). Tharenou (2005) proposes that women's multiple roles act to reduce experience, training and development and therefore potentially reduce their managerial advancement in comparison with men. However, Elder and Johnson (2001) note that women are more likely to be educated to tertiary level in the workforce. Indeed, managerial and professional women are as welleducated and trained as their male counterparts (Burke, 1993). Yet, even when qualifications and experience are held constant, women are still at a disadvantage compared 
to men (Miller et al., 2004). So it is difficult to give credence to human capital explanations of women's lower participation rates within management and international assignments.

Human capital is captured in terms of 'knowing how' whereas social capital is captured by 'knowing whom' (Terjesen, 2005) (although issues of human capital and social capital become intertwined). Tharenou (2005) argues that although human capital is valuable to women's advancement, men advance more because of their social capital. She thus posits that women's lower social capital, more so than their human capital, explains why women do not advance to executive levels. Potentially, therefore, role models, networks and mentors can assist women's career advancement. Yet, female expatriate role models are lacking (Linehan and Walsh, 1999a). Peer relationships are valuable as they are not hierarchical and provide two-way support (Linehan, 2001) but once again the relative scarcity of women in international roles makes these rare. Women also face difficulties in accessing networks and mentors (Linehan and Walsh, 1999b) yet these are cited as critical to women gaining international opportunities (Linehan, 2001). Exclusion from (male) networks compounds women's professional isolation (Linehan and Walsh, 2000b), hinders career development (Shortland, 2011) and makes repatriation more difficult (Linehan and Scullion, 2002b); mentors can improve women expatriates' self-confidence, increase their visibility, promotional prospects and career advancement as well as facilitate their re-entry (Linehan and Walsh, 1999c). Women's reduced social capital thus helps to provide an explanation of their paucity as expatriates.

\section{Home and host country cultures: the societal cultural effect on women's expatriation}

It is a subject of debate as to whether host country cultural constraints present a barrier to women's acceptance by local nationals and/or whether home country perceptions, based on 
cultural stereotypes concerning local nationals' receptivity towards women as expatriates, are the major blockage to increasing women's opportunities to take up international positions. Nonetheless, gender stereotyping (whether it occurs in the home or the host country) and patriarchy affect female expatriates in two main ways: via the subtle bias that, as women, their capabilities may not be recognized and/or via the overt discrimination of having their efforts deliberately derailed (Caligiuri and Cascio, 1998).

There is clear evidence globally that, although women are increasingly able to take advantage of greater opportunities to pursue managerial careers, career blockages and discrimination present barriers to their advancement. This appears to be true for women in Western countries with gender-egalitarian images (Tienari, Søderberg, Holgersson and Vaara, 2005) as well as in those where gender discrimination is inherent within cultural norms, such as Japan (Wakisaka, 1997). Given the cultural differences between Japan and traditional Western sending locations, Japan is a frequent research base for evaluating women expatriates' adjustment and acceptance by local nationals. Taylor and Napier's (1996a, 1996b) findings reinforce some of Adler's (1987) research: women's visibility, their relationship building skills, their Japanese language skills and clear job roles aid their work adjustment. However, while Adler highlights the difficulties female expatriates face in Asia in gaining support from their male expatriate colleagues, Taylor and Napier (ibid.) report on the benefits that mentoring by Western colleagues brings to female expatriates' work adjustment. Volkmar and Westbrook's (2005) replication of Taylor and Napier's research finds an increase in the incidence of formal preparation, training and support given by employers to Western women working in Japan yet there is little progress in respect of the challenges that women face in adjustment, despite Japan's increasing Westernization of 
business practices and the increase in Japanese women's representation in management positions.

Harris and Harris $(1987,1988)$ claim that while Western women hold important positions in Japan and Japanese men are respectful and acceptant of them, the female expatriates experience discrimination, in particular, from Japanese women. Taylor and Napier (1996b) report resistance/sabotage by Japanese colleagues, subordinates (including female secretaries) and clients, together with exclusion from male bonding circles all hindering their adjustment. In addition, female expatriates' face challenges associated with their Western colleagues disbelieving that they can face discrimination.

Being single places particular pressure on female expatriates to build relationships and friendships to reduce social isolation. In societies where women are rarely found in the upper ranks of the corporate hierarchy, making friends presents a particular challenge (Taylor and Napier, 2001). In expatriate environments, particularly in compounds, support groups cater for wives (Coles and Fechter, 2008). Female expatriates lead separate lives to those of expatriates' wives by the nature of their working hours or through choice. Thus, they are excluded or exclude themselves from female support groups (Fechter, 2008). Yet, female expatriates also find it difficult to be incorporated within expatriate networks which tend to be male-dominated (Linehan and Walsh, 2000b); yet male-dominated environments can result in women being in particular need of networking support to address both social and career issues (Shortland, 2011).

Research into the experiences of American women working in Turkey (Napier and Taylor, 2002; Taylor and Napier, 2001), reports interviewees speaking of few Turkish women in senior levels in the workplace with whom to develop friendships, more junior women colleagues being uncomfortable socializing with them while local women occupied 
with family concerns view them as a threat through their single and foreign status. Yet, research into expatriate job performance in Turkey using host country national ratings indicates that male and female expatriates are rated similarly despite Western perceptions suggesting the culture in Turkey to be ill-disposed towards foreign women managers (Sinangil and Ones, 2003).

The Middle East is typically thought of as a region characterized by uncertainty and instability (Özbilgin and Healy, 2003), being one of the most difficult geographical areas for Western women to operate within. Yet, Dallalfar and Movahedi's (1996) study of white American and Western European expatriate men and women working for MNCs in Iran indicates a 'women's advantage' model; the women expatriates did perform more effectively than their male counterparts. More recent research in Iran (Ghorbani and Tung, 2007) demonstrates that women can participate actively in most fields of study at university and can work in most occupations suggesting that reconsideration of an all-male policy in respect of expatriation is needed. Later evidence of female expatriates' successful adjustment in this region comes from Harrison and Michailova's (2012) study of Western female expatriates in the UAE, even though the female expatriates in their study are seen first as women and secondly as professionals, contrasting with Adler's (1987) Asian findings. Of course, it can be argued that expatriate 'bubble' environments (such as in expatriate compounds in the Middle East) reduce the requirement for cross-cultural adjustment, and potentially aid women's settling-in. Yet, Hutchings, Michailova and Harrison's forthcoming study suggests that women in such environments do not operate in a truly expatriate ghetto but neither do they live nor work in a fully cosmopolitan setting. 
That said, compounds are known for their 'in-groups' and fitting into these brings its own pressure to conform (Lauring and Selmer, 2009).

Although research to date does not control systematically for expatriates' culture of origin on their adjustment (Waxin, 2006) or local acceptance, evidence concerning the success of expatriate women from various home countries can be drawn from across the world regardless of the receiving host country's local culture. In India, for example, Varma, Toh and Budhwar's (2006) research finds American female expatriates preferred over men as co-workers by Indian local nationals. In South Africa, stories of women's success and career growth as a result of expatriate assignments are also in evidence (Mathur-Helm, 2002).

In essence, the literature suggests that female expatriates are, in the main, seen firstly as foreign professionals rather than as women per se. Thus, while the uniqueness of the host cultural locality affects the career progress, in particular, of local women, expatriate women by contrast are not seen in a gender context in their receiving host nations but rather as emissaries of their sending corporations. Even where Western women expatriates are seen first as women, as in Harrison and Michailova's (2012) research in the UAE, they do well in their assignments. This points to the conclusion that women can succeed as expatriates and that foreigners' prejudice is, in effect, a home country cultural perception - a 'pervasive myth' (van der Boon, 2003).

However, the ethnicity of the expatriate women does appear to be significant. Women of Japanese and Chinese descent working in Japan and China are found to face greater initial resistance than their Caucasian counterparts (Napier and Taylor, 2002). 
Tzeng's (2006) research into the experiences of female expatriates working in Western MNCs in Taiwan suggests that while local reaction to expatriate women of non-Chinese ethnicity reflects Adler's (1987) findings, expatriate women who more closely resemble the ethnicity of locals are treated to a greater extent like local women and face greater gender discrimination as a result, particularly from men of the same ethnic background.

Vance and Paik (2001) and Paik and Vance (2002) assert that women face the biggest obstacle to career success as expatriates at home, in their own 'backyard'. They note that US managers posting female expatriates abroad demonstrate a selection bias which is not replicated in their receiving countries. Four main reasons are given for this: fears over cultural restrictions as to what women cannot do; the predominance of men who are more aggressive in their business dealings; men being better qualified for international assignments; and the inability of women to rise to the challenge and adjust successfully. However, the authors say that these reasons are unfounded. Vance and Paik (2001) also note that there appears to be no differences across generations in the perceptions of home country managers regarding American women's ability to succeed abroad, although organizations which are more successful in promoting women at home are less likely to apply a selection bias in respect of women's international mobility.

As Shortland (2009) states studies conducted across the globe examine whether the host societal culture views women as unsuitable due to their gender. Regardless of destination, women are successful as expatriates particularly if they do not resemble local women; it is therefore suggested that home country prejudice linked to "cultural stereotyping of pre-supposed norms in the host country outweighs actual host country prejudice" (p. 377) while local patriarchal attitudes towards local women are applied to foreign women who closely resemble them. 


\section{Explanations of female expatriation from societal cultural theory}

Schwartz's (1992) work on culture concerns dimensions such as self-transcendence and self-enhancement and is potentially of relevance in explaining the 'backyard' effect. The self-transcendence dimension reflects the notion of accepting others on their merits while the self-enhancement dimension refers to the pursuit of self-interest. Potentially the dominance of the 'backyard' in influencing women's selection reflects sending managers' preference for self-enhancement, rather than accepting female candidates on their merits. A further bi-polar dimension can also be invoked as explanation - that of conservation versus openness to change - the first dimension stresses security and conformity while the latter suggests independence and action. The dominance of the 'backyard' here may be related to preferences by the home managers for security and conformity. Cole and McNulty (2011) suggest that female expatriates have higher self-transcendence than men. If women play a lesser role in expatriate selection than do men, this might further explain why women are less likely than men to be selected for expatriation.

Female expatriate selection is therefore potentially linked to a greater extent to more general gender stereotyping than societal cultural dimensions. Assumptions cannot be made of cultural coherence within every society (Pfau-Effinger, 1999) and, even if every culture has its own values and beliefs about the correct behaviors of men and women, Woodward (1996) suggests that, as the rules concerning these in multicultural situations are unclear, actors apply stereotypical gender solutions, following strong expectations in respect of gender. Thus, even in feminine cultures, she suggests, male solidarities keep women out. Yet, Janssens, Cappellen and Zanoni (2006) find that women expatriates can produce effective professional identities when they interact with men: as active agents they can 
interpret their interactions with men and position themselves drawing from gender, hierarchy and culture to enable, rather than constrain their actions. In essence, successful female expatriates interpret and make sense of male-female interactions, positioning themselves using individual strategies to enable them to feel most powerful.

\section{Institutional effects on women's expatriate participation}

Becker (1971) suggests that it is a rational economic choice for employers to discriminate between groups of workers if the cost involved in the decision to identify one particular group over the other as being suitable exceeds that of sustaining the differences between the abilities of the groups of workers. As such, statistical discrimination theory implies that the cost of identifying women's suitability exceeds that of maintaining gender bias; in essence, it is economically rational to discriminate between women and men as the cost of identifying women as suitable expatriates is too high. Yet, as Anker (2001) notes, less prejudiced employers decrease their costs and increase profits by employing women and, at the individual level, as Hareli, Klang and Hess (2008) suggest, once having held a gender atypical job, men and women are perceived as more suited to holding future atypical sex roles. This indicates that career history can help to reduce gender bias for women.

Gendered structures within labour markets result in occupational segregation - both horizontal and vertical (Blackburn and Jarman, 2005a; Siltanen, Jarman and Blackburn 1995). Occupations tend to polarize into those with high male or female concentrations; with segregation measuring its degree. Female occupations refer to those where the proportion of women working in them is greater than women's representation in the labour force (Blackburn and Jarman, 2005a). Expatriate work remains strongly horizontally 
gender-segregated. Vertical segregation refers to the gender inequality which results from women's concentration in the lower echelons of organizational hierarchies (Siltanen et al., 1995). Horizontal segregation affects vertical segregation - the smaller the percentage of women in a profession, the lower their chances of getting to the top of it (Blackburn and Jarman, 2005b; Wirth, 2001). Despite a rising trend in women's labour market participation (International Labour Organization, 2007) women find it difficult to penetrate managerial ranks, particularly in male-dominated sectors. In more female-dominated sectors where women succeed to a greater extent in obtaining higher level jobs, men still hold significantly more managerial positions (Wirth, 2001).

Assisted by legislation and a changing social climate, women's representation in the managerial pool at lower and middle management levels is, however, slowly being translated into more senior appointments (Altman, Simpson, Baruch and Burke, 2005). Yet, women remain under-represented within powerful positions (e.g. Nielsen and Huse, 2010; Sealy, Vinnicombe and Doldor, 2009). Rubery, Smith and Fagan (1999) suggest that women's under-representation at senior levels might result from the age structure of women within management - a proxy for levels of experience. Yet, there has been little change over the years in women's appointments as directors within FTSE 100 companies (Sealy et al., 2009) and women's representation as heads of multinationals is 'miniscule' (Klenke, 1999). An explanation for the reinforcement of vertical segregation over time may lie in invisible (but firmly embedded) 'glass' barriers to women's career progress within organizations and as expatriates. As discussed earlier, the literature on glass ceilings and borders provides a descriptive framework of vertical occupational segregation of relevance to women's participation as expatriates. However, to understand why the relatively low employer demand for female expatriates is perpetuated, it is necessary to seek further 
theoretical explanation as to why organizations continue to take such similar approaches to female expatriate deployment and so little change is apparent.

\section{Isomorphic explanations for women's expatriate participation}

The concept of institutional isomorphism relates to where one unit resembles others facing the same environmental conditions (DiMaggio and Powell, 1983). The authors suggest three types of change that create isomorphic responses: 'coercive', resulting from political influence (including formal and informal pressures exerted by other organizations and through cultural expectations); 'mimetic', stemming from standard responses to uncertainty (under which, in poorly understood or ambiguous conditions, organizations model themselves on others through copying or borrowing of practices); and 'normative', linked to 'professionalization' (via professional education and networks). Short-term benefits gained through non-compliance with industry practice can result in retaliatory action. Hence, even in a rapidly changing environment, organizations adopt standard approaches and thus demonstrate considerable stability in their policies and practices (Ando, 2011; Blom-Hansen, 1997). When firms mimic the most successful policies and practices, this leads to greater uniformity rather than diversity of approaches (Chow, 2004). Organizations also adopt 'normative isomorphism' through their development of early careers as part of graduate fast track development programmes (drawing from similar universities and courses). This can result in 'mimicking people', meaning that those reaching the top are potentially barely distinguishable from each other due to this 'professionalization'. In addition, as management is 'professionalized' similarly and personnel and information are exchanged across organizations, professionals whose ideas are developed in this way then continue to exercise control systems based on their beliefs through normative processes (Scott, 1995). 
While a variety of institutional considerations play a role in maintaining occupational segregation and partially explain women's low expatriate participation, institutional isomorphic organizational behavior (DiMaggio and Powell, 1983) can be considered to be particularly pertinent as an underpinning. It leads to greater uniformity of approach than might be expected from competing entities (Chow, 2004) and thus it can be argued that isomorphic employer behavior cements the invisible 'glass' barriers in the workplace that disadvantage women through repeated reinforcement of employer policy and practice (Shortland, 2009).

\section{So do we really know why there are so few women expatriates?}

Much of the research into female expatriation is written from the perspectives of students (potential expatriates) and employers. Yet, we know from Andresen et al.'s (2006) research that willingness to expatriate and actually doing so are a different matter and, from Stroh et al.'s (2000a, 2000b) research, that the views of supervisors and female expatriates can differ. Hence, if we really wish to understand the issues that surround expatriation for women, we need valid data drawn from female expatriates themselves. However, the volume of work published in the academic, peer-reviewed literature based upon real women expatriates is very limited. For example, in the period from January 1980 through to December 2008, Shortland and Altman (2011) identified 64 articles that examined gender as a variable based upon just 38 different datasets relating to female corporate career expatriates (excluding self-initiated expatriates). Their findings examined (true to Adler's tripartite categorization) the effects of family issues and host nationals' receptivity on women's expatriation as well as the organizational angle - although in this case employer interventions that might support (or hinder) female expatriation throughout the expatriation 
cycle are considered, breaking away from the standard excuses as to why women were simply unsuited for international mobility.

Nonetheless, in considering organizational support, the female expatriate data analyzed, reaffirms selection bias. For example, Forster's $(1997,1999)$ study (one of the very few longitudinal research studies of women's expatriation) indicates that single and married women without children have a higher chance of being selected than mothers but in any event women assignees' destination locations are restricted to established expatriate communities and cultures presumed receptive to them. Moore's (2002) analysis of a largescale Catalyst survey suggests that stereotyping of women's lower international mobility disadvantages them in the selection process.

The types of assignments on offer from organizations are changing, with a move away from long-term traditional expatriation to alternative forms of international mobility such as short-term assignments and series of consecutive global postings (Collings, Scullion and Dowling, 2009). More flexible assignment types also include commuter assignments (Collings, Scullion and Morley, 2007). Yet, very little is known about the effect of these 'flexpatriate' assignments on women's expatriation. However, from Mayerhofer, Hartmann and Herbert's (2004) study, it is revealed that women are more likely to give up international assignments involving this kind of frequent mobility, putting their family life first.

With respect to organizational support once in post, Culpan and Wright (2002) find that this is of high value to women assignees' job satisfaction while Caligiuri, Joshi, and Lazarova (1999) say that this aids female assignees' cross-cultural adjustment. Networking is considered helpful to achieving cultural inclusion (Fish, 2005) and other support - such as pre-assignment trips and assistance to aid family integration - is also considered helpful 
(Mayrhofer and Scullion, 2002). Yet, Hutchings, French and Hatcher (2008) report that women assignees receive less perceived organizational support than do men and Selmer and Leung (2003d) find that support interventions such as career counseling and planning are less available to women than to men. Mentoring and access to networks are found to be highly valuable to female assignees' repatriation; yet again a lack of support of this nature is evident (Linehan and Scullion, 2002a, 2002b, 2002c).

One of the key problems that Shortland and Altman (2011) identify concerns not only the relative paucity of female expatriate datasets but also the small sample sizes used. Of course, in the early literature, this is a reflection of the scarcity of female expatriates but there is less excuse for this today, given that expatriate numbers are rising and women's proportion of the total expatriate population is much higher now than in the 1980s. Yet, small samples still dominate research; only four of the identified datasets drawing upon interview research comprise sample sizes of 50 or more women. Well-known studies such as Harris's (2002) work on selection and Mayerhofer et al.'s (2004) research on flexpatriation draw upon interviews with just six and five female expatriates respectively. In addition, the literature relies strongly on single source data and snowball sampling is often used to source interviewees; such methods introduce potential bias. With respect to surveys of female expatriates, the literature is often silent on response rates or these are low, resulting in questions over potential generalization from the data. Further problems with the datasets on women's expatriation include the snapshot nature of data collection (we do not know effects over time); the wide range of geographies studied (sometimes from the host country perspective, sometimes from the sending location; occasionally both) and the emphasis on Western sending and receiving countries (such that we know very little about other home/host pairings). This latter point is of major concern given the increasing 
organizational emphasis on developing business in emerging economies and on transferring expatriates to developing countries where they have little previous experience or knowledge to facilitate this process (Santa Fe Group, 2012). Added to this, Shortland and Altman (2011) note that the majority of the articles published lack theoretical underpinning, being only practice-driven; where a theoretical context is set out, this varies widely from research study to research study.

While recognizing the difficulties researchers face and the necessity to work with what you can get (and in no way belittling that published already), we must be aware of the effect of all of these issues. In essence, we have only a patchwork understanding of women's expatriation and generalization becomes very tricky (if not suspect) as a result. As Shortland and Altman (2011) suggest, ideally we need: a focus on the most promising theoretical lenses to frame future research; systematic profiles of women assignees; strong methodological designs; longitudinal research; and comparative studies, particularly to explore women's expatriation experiences vis-à-vis men's. To understand why women's participation in expatriation appears to have now stalled and to increase gender expatriate diversity in the future, further research is required. We need to know whether, and if so how and why, women's expatriate careers are constrained. Women's expatriation requires attention in its own right if any meaningful change is to take place and expatriate gender diversity is to increase in the future.

\section{References}

Ackers, L. (2004), 'Managing relationships in peripatetic careers: scientific mobility in the European Union', Women's Studies International Forum, 27 (3), 189-201. 
Adler, N.J. (1979), 'Women as androgynous managers: a conceptualization of the potential for American women in international management', International Journal of Intercultural Relations, 3 (4), 407-436.

Adler, N.J. (1984a), 'Women do not want international careers: and other myths about international management', Organizational Dynamics, 13, 66-79.

Adler, N.J. (1984b), 'Expecting international success: female managers overseas', Columbia Journal of World Business, 19 (3), 79-85.

Adler, N.J. (1987), 'Pacific basin managers: a gaijin, not a woman', Human Resource Management, 26 (2), 169-191.

Adler, Nancy J. (2011), 'Women leading and managing worldwide', in: Anne-Wil Harzing and Ashly H. Pinnington (eds) International human resource management, London: Sage, pp. 507-537.

Altman, Yochanan, Ruth Simpson, Yehuda Baruch and Ronald J. Burke (2005), 'Reframing the 'glass ceiling' debate', in Ronald J. Burke and Mary C. Mattis (eds), Supporting women's career advancement: challenges and opportunities. Cheltenham, UK and Northampton, MA, US: Edward Elgar, pp. 58-81. 
Ando, N. (2011), 'Isomorphism and foreign subsidiary staffing policies', Cross Cultural Management: An International Journal, 18 (2), 131-143.

Andresen, Maike, Elena Hristozova and Uta B. Lieberum (2006), 'Gender diversity and organizational success: the impact of female foreign assignments', in Michael J. Morley, Noreen Heraty and David G. Collings (eds), New Directions in Expatriate Research. Basingstoke, UK: Palgrave Macmillan, pp. 142-165.

Anker, Richard (2001), 'Theories of occupational segregation by sex: an overview', in Martha F. Loutfi (ed), Women, Gender and Work: What is Equality and How Do We Get There? Geneva: International Labour Organization, pp. 129-155.

Anonymous (2007), 'More women sent on international assignment', Compensation and Benefits Review. 39 (2), 14-15.

Auster, E.R. (1993), 'Demystifying the glass ceiling: organizational and interpersonal dynamics of gender bias', Business \& The Contemporary World, 5 (3), 47-68.

Becker, Gary S. (1971), The Economics of Discrimination, Chicago, IL, US: University of Chicago Press.

Becker, Gary S. (1981), A Treatise on the Family. Cambridge, MA, US: Harvard University Press. 
Blackburn, Robert M. and Jennifer Jarman (2005a), Segregation and Inequality, GeNet 2005-3, Economic \& Social Research Council Gender Equality Network, www.genet.ac.uk/workpapers/index.html, accessed 6 December 2005.

Blackburn, Robert M. and Jennifer Jarman (2005b), Gendered Occupations: Exploring the Relationship between Gender Segregation and Inequality, GeNet 2005-5, Economic \& Social Research Council Gender Equality Network, www.genet.ac.uk/workpapers/index.html, accessed 6 December 2005.

Blom-Hansen, J. (1997), 'A 'new institutional' perspective on policy networks', Public Administration, 75, 669-693.

Brett, J.M. and L.K. Stroh (1995), 'Willingness to relocate internationally', Human Resource Management, 34 (3), 405-424.

Brookfield (2012), Global Relocation Trends: 2012 Survey Report, Chicago, IL, US: Brookfield Global Relocation Services.

Bruegel, I. (1996), 'Whose myths are they anyway?: a comment', British Journal of Sociology, 47 (1), 175-177.

Burke, R.J. (1993), 'Women in corporate management: introduction', Business \& The Contemporary World, 5 (3), 3-9. 
Burke, R.J. and C.A. McKeen (1993), 'Supporting the career aspirations of managerial and professional women', Business \& The Contemporary World, 5 (3), 69-80.

Burke, R. and S. Vinnicombe (2005), ‘Advancing women's careers', Career Development International, 10 (3), 165-167.

Caligiuri, P.M. and W.F. Cascio (1998), 'Can we send her there? Maximizing the success of western women on global assignments’ Journal of World Business, 33 (4), 394-416.

Caligiuri, P. M., A. Joshi and M. Lazarova (1999), 'Factors influencing the adjustment of women on global assignments', The International Journal of Human Resource Management, 10 (2), 163-179.

Chan, B. and M. Smith (2000), 'City limits', Management Accounting. July/August, 3840.

Chew, I.K.H. and W. Zhu (2002), 'Factors influencing Singapore managers' career aspiration in international assignments', Career Development International, 1 (7), 52-57.

Chow, I.H. (2004), 'The impact of institutional context on human resource management in three Chinese societies', Employee Relations, 26 (6), 626-642. 
Chusmir, L.H. and N.T. Frontczak (1990), 'International management opportunities for women: women and men paint different pictures', International Journal of Management, 7 (3), 295-301.

Cole, N. and Y. McNulty (2011), "Why do female expatriates "fit-in" better than males? An analysis of self-transcendence and socio-cultural adjustment', Cross Cultural Management: An International Journal, 18 (2), 144-164.

Coles, Anne and Anne-Meike Fechter (2008), 'Introduction', in: Anne Coles and AnneMeike Fechter (eds), Gender and Family among Transnational Professionals, London: Routledge, pp. 1-20.

Collings, D.G., H. Scullion and P.J. Dowling (2009), 'Global staffing: A review and thematic research agenda', The International Journal of Human Resource Management, 20 (6), 1253-1272.

Collings, D.G., H. Scullion and M.J. Morley (2007), 'Changing patterns of global staffing in the multinational enterprise: Challenges to the conventional expatriate assignment and emerging alternatives', Journal of World Business, 42, 198-213.

Corrigall, E.A. and A.M. Konrad (2006), 'The relationship of job attribute preferences to employment, hours of paid work, and family responsibilities: an analysis comparing women and men', Sex Roles, 54 (1/2), 95-111. 
Crompton, R. and F. Harris (1998), 'Explaining women's employment patterns:

'orientations to work' revisited', British Journal of Sociology, 49 (1), 118-136.

Culpan, O. and G.H. Wright (2002), 'Women abroad: getting the best results from women managers', The International Journal of Human Resource Management, 13 (5), 784-801.

Daley, D.M. (1998), 'Attribution theory and the glass ceiling: career development among federal employees', International Journal of Organization Theory \& Behavior, 1 (1), 93116.

Dallalfar, A. and S. Movahedi (1996), 'Women in multinational corporations: old myths, new constructions and some deconstruction', Organization, 3 (4), 546-559.

Diem-Wille, Gertraud and Judith Zeigler (2000), ‘Traditional or new ways of living', in Mino Vianello and Gwen Moore (eds), Gendering elites: economic and political leadership in 27 industrialised societies, Basingstoke, UK: Macmillan Press, pp. 169-176.

DiMaggio, P.J. and W.W. Powell (1983), 'The iron cage revisited: institutional isomorphism and collective rationality in organizational fields', American Sociological Review, 48, 147-160.

Dupuis, M.-J., V.Y. Haines III and T. Saba (2008), 'Gender, family ties, and international mobility: cultural distance matters', The International Journal of Human Resource Management, 19 (2), 274-295. 
Edström, A. and J.R. Galbraith (1977), 'Transfer of managers as a coordination and control strategy in multinational organizations', Administrative Science Quarterly, 22, 248-263.

Egan, M.L. and M. Bendick, Jr. (1994), 'International business careers in the United States: salaries, advancement and male-female differences', The International Journal of Human Resource Management, 5 (1), 33-50.

Elder, Sara and Lawrence J. Johnson (2001), 'Sex-specific labour market indicators: what they show', in Martha F. Loutfi (ed), Women, Gender and Work: What is Equality and How Do We Get There? Geneva: International Labour Organization, pp. 251-272.

Fechter, Anne-Meike (2008), 'From 'incorporated wives' to 'expat girls': a new generation of expatriate women?', in: Anne Coles and Anne-Meike Fechter (eds), Gender and Family among Transnational Professionals, London: Routledge, pp. 193-209.

Fischlmayr, I.C. (2002), 'Female self perception as barrier to international careers?', The International Journal of Human Resource Management, 13 (5), 773-783.

Fish, A. (2005), 'Assisting cross-border manager adjustment: psycho-cultural and sociocultural interventions', Personnel Review, 34 (2), 225-245.

Forster, N. (1997), 'The persistent myth of high expatriate failure rates': a reappraisal', The International Journal of Human Resource Management, 8 (4), 414-433. 
Forster, N. (1999), 'Another 'glass ceiling'?: The experiences of women professionals and managers on international assignments', Gender, Work \& Organization, 6 (2), 79-90.

Ghorbani, M. and R.L. Tung (2007), 'Behind the veil: an exploratory study of the myths and realities of women in the Iranian workforce', Human Resource Management Journal, 17 (4), 376-392.

Gordon, G.D. and M.B. Teagarden (1992), 'Corporate selection strategies and international manager success', in Expatriate management- $1^{\text {st }}$ international conference, Hong Kong: Hong Kong Baptist College, School of Business, pp.17-24.

Gordon, J.R. and K.S. Whelan-Berry (2004), 'It takes two to tango: an empirical study of perceived spousal support for working women', Women in Management Review, 19 (5), $260-273$.

Haines III, V.Y. and T. Saba (1999), 'International mobility policies and practices: are there gender differences in importance ratings?' Career Development International, 4 (4), 206211.

Hakim, Catherine (2000), Work-lifestyle choices in the $21^{\text {st }}$ century. Oxford: Oxford University Press. 
Hardill, I. (1998), 'Gender perspectives on British expatriate work', Geoforum, 29 (3), 257 268.

Hardill, I., A.E. Green, A.C. Dudleston and D.W. Owen (1997), 'Who decides what?

Decision making in dual-career households', Work, Employment and Society, 11, 313-326.

Hardill, I. and S. MacDonald (1998), 'Choosing to relocate: an examination of the impact of expatriate work on dual-career households', Women's Studies International Forum, 21 (1), 21-29.

Hareli, S., M. Klang and U. Hess (2008), 'The role of career history in gender based biases in job selection decisions', Career Development International, 13 (3), 252-269.

Harris, H. (1992), Women expatriate managers: the double-glazing ceiling?', in Expatriate management- $1^{\text {st }}$ international conference, Hong Kong: Hong Kong Baptist College, School of Business, pp. 169-178.

Harris, H. (1993), 'Women in international management: opportunity or threat?', Women in Management Review, 8 (5), 9-14.

Harris, H. (2002), 'Think international manager, think male: why are women not selected for international management assignments?', Thunderbird International Business Review, 44 (2), 175-203. 
Harris, H. (2004a). 'Global careers. Work-life issues and the adjustment of women international managers', Journal of Management Development, 23 (9), 818-832.

Harris, Hilary (2004b), 'Women's role in international management', in Anne-Wil Harzing and Joris Van Ruysseveldt (eds), International Human Resource Management, London: Sage Publications, pp. 357-386.

Harris, H. and C. Brewster (1999), 'The coffee-machine system: how international selection really works', The International Journal of Human Resource Management, 10 (3), 488-500.

Harris, P.R. and D.L. Harris (1987), 'Update. Women managers and professionals abroad', Journal of Managerial Psychology, 2 (3), i-ii.

Harris, P.R. and D.L. Harris (1988), 'Opinion. Women managers and professionals abroad', Journal of Managerial Psychology, 3 (4), pp. i-ii.

Harrison, E.C. and S. Michailova (2012), 'Working in the Middle East: Western female expatriates' experiences in the United Arab Emirates', The International Journal of Human Resource Management, 23 (4), 625-644.

Harvey, M.G. (1995), 'The impact of dual-career families on international relocations', Human Resource Management Review, 5 (3), 223-244. 
Harvey, M. (1997), 'Dual-career expatriates: expectations, adjustment and satisfaction with international relocation', Journal of International Business Studies, 28 (3), 627-658.

Harvey, M. (1998), 'Dual career couples during international relocation: the trailing spouse', The International Journal of Human Resource Management, 9 (2), 309-331.

Hill, C.J. and K.R. Tillery (1992), 'What do male/female perceptions of an international business career suggest about recruitment policies?', SAM Advanced Management Journal, 57 (4), 10-14.

Hutchings, K., E. French and T. Hatcher (2008), 'Lament of the ignored expatriate: an examination of organisational and social network support for female expatriates in China', Equal Opportunities International, 27 (4), 372-391.

Hutchings, K., S. Michailova and E.C. Harrison (forthcoming), 'Neither ghettoed nor cosmopolitan: a study of Western women's perceptions of gender and cultural stereotyping in UAE', Management International Review, forthcoming.

International Labour Organization (2007), International Employment Trends for Women Brief. www.ilo.org/public/english/region/asro/jakarta/download/getwomen07.pdf, accessed 16 March 2007.

Izraeli, D.N., M. Banai and Y. Zeira (1980), 'Women executives in MNC subsidiaries.' California Management Review, 23 (1), 53-63. 
Janssens, M., T. Cappellen and P. Zanoni (2006), 'Successful female expatriates as agents: positioning oneself through gender, hierarchy, and culture', Journal of World Business, 41 (2), 133-148.

Jelinek, M. and N.J. Adler (1988), 'Women: world-class managers for global competition', The Academy of Management Executive, II (1), 11-19.

Kanter, Rosabeth M. (1977), Men and Women of the Corporation. New York, NY, US: Basic Books.

Klenke, K. (1999), 'Women leaders and women managers in the global community', Career Development International, 4 (3), 134-139.

Lauring, J. and J. Selmer (2009), 'Expatriate compound living: an ethnographic field study', The International Journal of Human Resource Management, 20 (7), 1451-1467.

Linehan, Margaret (2000), Senior Female Managers: Why So Few? Aldershot, UK: Ashgate Publishing.

Linehan, M. (2001), 'Networking for female managers' career development: empirical evidence', Journal of Management Development, 20 (10), 823-829. 
Linehan, M., (2002), 'Senior female international managers: empirical evidence from Western Europe', The International Journal of Human Resource Management, 13 (5), 802814.

Linehan, M. and H. Scullion (2001a), 'European female expatriate careers: critical success factors', Journal of European Industrial Training, 25 (8), 392-418.

Linehan, M. and H. Scullion (2001b), 'Selection, training, and development for female international executives', Career Development International, 6 (6), 318-323.

Linehan, M. and H. Scullion (2001c), 'Challenges for female international managers: evidence from Europe', Journal of Managerial Psychology, 16 (3), 215-228.

Linehan, M. and H. Scullion (2002a), 'The repatriation of female international managers: an empirical study', International Journal of Manpower, 23 (7), 649-658.

Linehan, M. and H. Scullion (2002b), 'Repatriation of European female corporate executives: an empirical study', The International Journal of Human Resource Management, 13 (2), 254-267.

Linehan, M. and H. Scullion (2002c), 'Repatriation of female executives: empirical evidence from Europe', Women in Management Review, 17 (2), 80-88. 
Linehan, M., H. Scullion and J.S. Walsh (2001), ‘Barriers to women’s participation in international management', European Business Review, 13 (1), 10-18.

Linehan, M. and J.S. Walsh (1999a), 'Senior female international managers: breaking the glass border', Women in Management Review, 14 (7), 264-272.

Linehan, M. and J.S. Walsh (1999b), 'Recruiting and developing female managers for international assignments', The Journal of Management Development, 18 (6), 521-530.

Linehan, M. and J.S. Walsh (1999c), 'Mentoring relationships and the female managerial career', Career Development International, 4 (7), 348-352.

Linehan, M. and J.S. Walsh (2000a), 'Work-family conflict and the senior female international manager', British Journal of Management, 11, 49-58.

Linehan, M. and J.S. Walsh (2000b), 'Beyond the traditional linear view of international managerial careers: a new model of the senior female career in an international context', Journal of European Industrial Training, 24 (2/3/4), 178-189.

Linehan, M. and J.S. Walsh (2001), 'Key issues in the senior female international career move: a qualitative study in a European context', British Journal of Management, 12 (1), $85-95$. 
Liu, J. and D. Wilson (2001), 'The unchanging perception of women as managers', Women in Management Review, 16 (4), 163-173.

Lowe, K.B., M. Downes and K.G. Kroeck (1999), 'The impact of gender and location on the willingness to accept overseas assignments', The International Journal of Human Resource Management, 10 (2), 223-234.

Mäkelä, K., M. Känsälä and V. Suutari (2011), 'The roles of expatriates' spouses among dual career couples', Cross Cultural Management: An International Journal, 18 (2), 185197.

Mathur-Helm, B. (2002), 'Expatriate women managers: at the crossroads of success, challenges and career goals', Women in Management Review, 17 (1), 18-28.

Mayerhofer, H., L.C. Hartmann and A. Herbert (2004), 'Career management issues for flexpatriate international staff', Thunderbird International Business Review, 46 (6), 647666.

Mayrhofer, W. and H. Scullion (2002), 'Female expatriates in international business: empirical evidence from the German clothing industry', The International Journal of Human Resource Management, 13 (5), 815-836. 
Miller, Linda., Fiona Neathey, Emma Pollard and Darcy Hill (2004), Occupational Segregation, Gender Gaps and Skill Gaps, Occupational segregation working paper series 15, Manchester, UK: Equal Opportunities Commission.

Moore, M. J. (2002), 'Same ticket, different trip: supporting dual-career couples on global assignments', Women in Management Review, 17 (2), 61-67.

Napier, N.K. and S. Taylor (2002), 'Experiences of women professionals abroad: comparisons across Japan, China and Turkey', The International Journal of Human Resource Management, 13 (5), 837-851.

Nielsen, S. and M. Huse (2010), 'The contribution of women on boards of directors: going beyond the surface', Corporate Governance: An International Review, 18 (2), 136-148.

ORC Worldwide (2007), 2006 Worldwide Survey of International Assignment Policies and Practices. New York, NY: ORC Worldwide.

Özbilgin, M. and G. Healy (2003), “'Don’t mention the war” - Middle Eastern careers in context', Career Development International, 8 (7), 325-327.

Paik, Y. and C.M. Vance (2002), 'Evidence of back-home selection bias against US female expatriates', Women in Management Review, 17 (2), 68-79. 
Perlmutter, H.V. (1969), 'The tortuous evolution of the multinational corporation', Columbia Journal of World Business, 4 (1), 9-18.

Pfau-Effinger, Birgit (1999), 'The modernization of family and motherhood in Western Europe', in Rosemary Crompton (ed), Restructuring Gender Relations and Employment: The Decline of the Male Breadwinner, Oxford: Oxford University Press, pp. 60-79.

Punnett, B.J., O. Crocker and M.A. Stevens (1992), 'The challenge for women expatriates and spouses: some empirical evidence', The International Journal of Human Resource Management, 3 (3), 585-592.

Rubery, Jill, Mark Smith and Collette Fagan (1999), Women's Employment in Europe: Trends and Prospects, London: Routledge.

Ruhe, J. A. and W. R. Allen (1997), 'Preparing women for careers in international management', Journal of Education for Business, 72 (5), 278-282.

Santa Fe Group (2012), Global Mobility Survey Report 2012: Exploring the Changing Nature of International Mobility, Hong Kong: Santa Fe Group.

Schein, V. (1973), 'The relationship between sex role stereotypes and requisite management characteristics', Journal of Applied Psychology, 57 (2), 95-100. 
Schwartz, S.H. (1992), 'Universals in the content and structure of values: theoretical advances and empirical tests in 20 countries', Advances in Experimental Social Psychology, 25, 1-65.

Scott, W. Richard (1995), Institutions and Organizations, London: Sage Publications.

Sealy, Ruth, Susan Vinnicombe and Elena Doldor (2009), The Female FTSE Board Report 2009, Cranfield, UK: Cranfield School of Management.

Selmer, J. and A.S.M. Leung (2002), 'Career management issues of female business expatriates', Career Development International, 7 (6), 348-358.

Selmer, J. and A.S.M. Leung (2003a), 'Provision and adequacy of corporate support to male expatriate spouses: an exploratory study', Personnel Review, 32 (1), 9-21.

Selmer, J. and A.S.M. Leung (2003b), 'International adjustment of female vs. male business expatriates', The International Journal of Human Resource Management, 14 (7), $1117-1131$.

Selmer, J. and A.S.M. Leung (2003c), 'Expatriate career intentions of women on foreign assignments and their adjustment', Journal of Managerial Psychology, 18 (3), 244-258. 
Selmer, J. and A.S.M. Leung (2003d), 'Are corporate career development activities less available to female than to male expatriates?', Journal of Business Ethics, 43 (1-2), 125136.

Shortland, S. (2009), 'Gender diversity in expatriation: evaluating theoretical perspectives', Gender in Management, 24 (5), 365-386.

Shortland, S. (2011), 'Networking: A valuable career intervention for women expatriates?', Career Development International, 16 (3), 271-292.

Shortland, S. and Y. Altman (2011), 'What do we really know about corporate career women expatriates?', European Journal of International Management, 5 (3), 209-234.

Siltanen, Janet, Jennifer Jarman and Robert M. Blackburn (1995), Gender Inequality in the Labour Market: Occupational Concentration and Segregation. A Manual on Methodology. Geneva: International Labour Organization.

Sinangil, H.K. and D.S. Ones (2003), 'Gender differences in expatriate job performance', Applied Psychology: An International Review, 52 (3), 461-475.

Sriskandarajah, Dhananjayan and Catherine Drew (2006), Brits abroad: mapping the scale and nature of British emigration, London: Institute for Public Policy Research. 
Stone, R.J. (1991), 'Expatriate selection and failure', Human Resource Planning, 14 (1), 918.

Stroh, Linda K., Arup Varma and Stacey J. Valy-Durbin (2000a), 'Women and expatriation: revisiting Adler's findings', in Davidson, Marilyn J. and Ronald J. Burke (eds), Women in Management, London: Sage, pp. 104-119.

Stroh, L.K., A. Varma and S.J. Valy-Durbin (2000b), 'Why are women left at home: are they unwilling to go on international assignments?', Journal of World Business, 35 (3), 241-255.

Suh, S. and M-S. Lee (2006), 'Group work for Korean expatriate women in the United States: an exploratory study', The Journal for Specialists in Group Work, 31 (4), 353-369.

Taillieu, T. (1992), 'International career directions of young European graduates', European Management Journal, 10 (2), 255-263.

Taylor, S. and N. Napier (1996a), 'Working in Japan: lessons from women expatriates', Sloan Management Review, 37 (3), 76-84.

Taylor, S. and N.K. Napier (1996b), 'Successful women expatriates: the case of Japan', Journal of International Management, 2 (1), 51-78. 
Taylor, S. and N.K. Napier (2001), 'An American woman in Turkey: adventures unexpected and knowledge unplanned', Human Resource Management, 40 (4), 347-364.

Terjesen, S. (2005), 'Senior women managers' transition to entrepreneurship', Career Development International, 10 (3), 246-259.

Thal, N.L. and P.R. Cateora (1979), 'Opportunities for women in international business', Business Horizons, 22 (6), 21-27.

Thang, L.L., E. MacLachlan and M. Goda (2002), 'Expatriates on the margins - a study of Japanese women working in Singapore', Geoforum, 33 (4), 539-551.

Tharenou, P. (2003), 'The initial development of receptivity to working abroad: selfinitiated international work opportunities in young graduate employees', Journal of Occupational and Organizational Psychology, 76 (4), 489-515.

Tharenou, Phyllis (2005), 'Women's advancement in management: what is known and future areas to address', in Ronald J. Burke and Mary C. Mattis (eds), Supporting women's career advancement: challenges and opportunities, Cheltenham, UK and Northampton, MA, US: Edward Elgar, pp. 31-57.

Tienari, J., A.M. Søderberg, C. Holgersson and E. Vaara (2005), 'Gender and national identity constructions in the cross-border merger context', Gender, Work and Organization. $12(3), 217-241$. 
Tung, R.L. (1982), 'Selection and training procedures of US, European and Japanese multinationals', California Management Review, 25 (1), 57-71.

Tung, R.L. (1998), ‘American expatriates abroad: from neophytes to cosmopolitans’, Journal of World Business, 33 (2), 125-144.

Tzeng, R. (2006), 'Gender issues and family concerns for women with international careers: female expatriates in Western multinational corporations in Taiwan', Women in Management Review, 21 (5), 376-392.

Vance, Y. and Y. Paik (2001), 'Where do American women face their biggest obstacle to expatriate career success? Back in their own backyard', Cross Cultural Management, 8 (3/4), 98-116.

van der Boon, M. (2003), 'Women in international management: an international perspective on women's ways of leadership', Women in Management Review, 18 (3), 132146.

van der Velde, M.E.G., C.J.H. Bossink and P.G.W. Jansen (2005), 'Gender differences in the determinants of the willingness to accept an international assignment', Journal of Vocational Behavior, 66, 81-103. 
Varma, A. and L.K. Stroh (2001), 'Different perspectives on selection for international assignments: the impact of LMX and gender', Cross Cultural Management, 8 (3/4), 85-97.

Varma, A., L.K. Stroh and L.B. Schmitt (2001), 'Women and international assignments: the impact of supervisor-subordinate relationships', Journal of World Business, 36 (4) 380388.

Varma, A., S.M. Toh and P. Budhwar (2006), 'A new perspective on the female expatriate experience: the role of host country national categorization', Journal of World Business, 41, 112-120.

Volkmar, J.A. and K.L. Westbrook (2005), 'Does a decade make a difference? A second look at western women working in Japan?', Women in Management Review, 20 (7), 464477.

Wakisaka, Akira (1997), 'Women at Work', in Mari Sako and Hiroko Sato (eds), Japanese Labour and Management in Transition,. London: Routledge, pp. 131-150.

Wang, B.C.Y. and N. Bu (2004), 'Attitudes toward international careers among male and female Canadian business students after 9-11', Career Development International, 9 (7), 647-672. 
Waxin, Marie-France (2006), 'The effect of culture of origin on the adjustment process assignments', in Michael J. Morley, Noreen Heraty and David G. Collings (eds), New Directions in Expatriate Research. Basingstoke, UK: Palgrave Macmillan, pp. 120-141.

Westwood, R.I. and S.M. Leung (1992), 'Expatriate female managers in Hong Kong; a gweipo, not a woman', in Expatriate management- $1^{\text {st }}$ international conference, Hong Kong: Hong Kong Baptist College, School of Business, pp. 157-168.

Westwood, R.I. and S.M. Leung (1994), 'The female expatriate manager experience', International Studies of Management and Organization, 24 (3), 64-85.

Wirth, Linda (2001), 'Women in management: closer to breaking through the glass ceiling?', in Martha F. Loutfi (ed), Women, Gender and Work: What is Equality and How Do We Get There? Geneva: International Labour Organization, pp. 239-250.

Woodward, Alison E. (1996), 'Multinational masculinities and European bureaucracies', in David L. Collinson and Jeff Hearn (eds), Men as Managers, Managers as Men: Critical Perspectives on Men, Masculinities and Managements, London: Sage Publications, pp. $167-185$.

Yeoh, B.S.A. and K. Willis (2005), 'Singaporeans in China: transnational women elites and the negotiation of gendered identities', Geoforum, 36 (2), 211-222. 
Zhu, W., F. Luthans, I.K.H. Chew and C. Li (2006), 'Potential expats in Singaporean organizations', Journal of Management Development, 25 (8), 763-776. 